\title{
Effect of Protease Supplementation on Growth Performances, Carcass and Meat Quality Characteristics of Broiler Chicken Fed with Low Protein Diets
}

\author{
T.D.L.M. Sumanasekara ${ }^{1}$, W.A.D. Nayananjalie ${ }^{* 1}$, L. Ang $^{2}$ and M.A.A.P. Kumari ${ }^{1}$
}

${ }^{1}$ Department of Animal and Food Sciences, Faculty of Agriculture, Rajarata University of Sri Lanka, Puliyankulama, Anuradhapura, Sri Lanka

${ }^{2}$ Pussalla Feed Mill, Dehigahahena waththa, Udamapitigama, Dompe, Sri Lanka

\section{Correspondence:}

*nayananjalie@yahoo.com

(iD) https://orcid.org/0000-0002-5225-0074

DOI: http://doi.org/10.4038/sljae.v2i2.42

\begin{abstract}
The effect of feeding low dietary crude protein (CP) with different levels of supplemental protease enzyme on commercial broilers was investigated. Threehundred broiler chicks were divided into five treatments with six replicates in a completely randomized design. The experimental diets were positive control (recommended CP levels, T1), negative control (level of CP reduced by 5\%, T2), negative control $+300 \mathrm{~g} \mathrm{t}^{-1}$ protease (T3), negative control $+400 \mathrm{~g} \mathrm{t}^{-1}$ protease (T4) and negative control $+500 \mathrm{~g} \mathrm{t}^{-1}$ protease (T5). Growth, blood serum, carcass quality and meat quality parameters were measured. Data were analysed using one-way Analysis of Variance. The highest live weight ( $2.86 \pm 0.07 \mathrm{~kg})$, weight gain $(2.66 \pm 0.05 \mathrm{~kg})$ and the lowest feed conversion ratio $(1.84 \pm 0.06)$ were observed in birds fed with T5. There was no influence of treatments $(p>0.05)$ on $\mathrm{NH}_{3}$ emission from litter, dressing percentage, meat quality and blood serum parameters. The feed cost per producing $1 \mathrm{~kg}$ of live weight and sellable carcass weight was significantly low $(p<0.05)$ in T5. Thus, it can be concluded that low protein diets supplemented with protease enzyme at $500 \mathrm{~g} \mathrm{t}^{-1}$ support better growth performances in broiler chicken with a lower cost of production.
\end{abstract}

Keywords: Broilers, Low protein diets, Performances, Protease enzyme 


\section{Introduction}

The demand of the world market for poultry products is rapidly rising with the growing population. The broiler sector has a vital role to make people food secure, in both economically and nutritionally. It has been estimated by the Food and Agriculture Organization that as of 2024, broiler meat production will reach 134 million metric tons (Anon 2018). With the increasing population, it was predicted that meat consumption per person per year will increase by $26 \%$ from 2006 to 2030 and this increase is mainly for chicken meat (OECD-FOA 2010). Therefore, the poultry industry has to grow continuously to meet the increasing demand. Hence, to supply the increasing demand, the broiler industry needs to be further commercialized, aiming at higher profits to the owner.

The poultry industry had changed dramatically in both nutritional and genetic components for achieving production targets (Gunal et al. 2006). In 1925, a broiler chicken took about 120 days to reach $1.5 \mathrm{~kg}$ of body weight, while in 2005 , it was only 30 days due to intensive selection \& breeding, and nutrition (Bessei 2006). Though genetic components are rapidly changed, it is not adequate to achieve higher production. In addition, improved nutrition and proper management are also essential.

Proper feeding of broilers is one of the main practices that producers have to consider, where feed cost contributes $60-70 \%$ of total production cost (Dosković et al. 2013). For cost-saving on feed, knowledge on digestive tract characteristics of poultry, nutrient requirements, digestion and nutrient utilization at certain growth and development stages is essential (Dosković et al. 2013). Currently, farmers are using highcost feed ingredients and supplements to supply enough nutrients for broilers to achieve higher performances. However, birds do not absorb all the nutrients available in feed rations. The undigested nutrients, especially proteins and amino acids, are utilized by the microbes for their metabolism in the hindgut resulting in an acidic condition (Moughan et al. 2014). Many studies have been conducted on broiler nutrition based on exogenous enzymes that could use in broiler feeds to attain maximum utilization efficiency.

Generally, the aims of adding enzymes to the broiler rations are to increase the digestibility, remove the anti-nutritional factors, improve the availability of nutrients and reduce the environmental issues (Hedstrom 2002). Many studies suggested 
that various types of endogenous protease are synthesized and released by the gastrointestinal tract, and they are sufficient to utilize feed protein at the optimum level. However, Dosković et al. (2013) suggest that the birds in their early stages might produce limited amounts of endogenous enzymes. These enzymes are necessary to digest higher amounts of vegetable proteins (Bedford 2009). It affects the nutrient digestibility of broilers in young ages. Therefore, protease enzyme can be used as supplementation to increase the digestibility of protein ingredients in the ration while it decreases the amount of dietary protein in the feed ration. This also reduces the protein waste and excretion of nitrogen into the environment (Ghazi et al. 2002).

Further, most of the broiler farmers use soybean meal as the protein source but, it contains several anti-nutrient factors. Though heat treatments apply to reduce the anti-nutrient factors, they are not totally inactivated (Maidala et al. 2013). Further, prolonged heating will result in the reduction of nutritional value. Hence, the use of exogenous enzymes to inactivate the proteinaceous anti-nutritional factors is a better method. Addition of exogenous enzymes results in better flock performances, quality of litter and improved bird health which in return, has a positive influence on total production costs (Cowieson and Ravindran 2008). Ultimately, supplementation of exogenous proteases on broiler rations improves the production efficiency by increasing the low-quality ingredient digestibility and reducing the losses of nutrients through excreta. It retains nutrient levels in rations resulting economic benefits to the farmer (Ghazi et al. 2002). Therefore, this research aimed to investigate the possibility of decreasing dietary protein levels in feed by adding protease enzyme to the broiler feed rations without interfering growth performances and carcass quality.

\section{Materials and Methods}

\section{Experiment Location}

Fieldwork and laboratory analysis were conducted at the livestock farm and laboratory of New Hope Lanka Ltd. Ekala, JaEla, Sri Lanka. Blood serum parameters and meat colour were analysed at the Animal Science laboratory in the Faculty of Agriculture, Rajarata University of Sri Lanka, Puliyankulama, Anuradhapura, Sri Lanka.

\section{Experimental Design}

Three hundred "Cobb 500", day-old broiler chicks were purchased from a commercial hatchery (CIC farm, Sri Lanka) and randomly assigned into five treatments designated as 
$\mathrm{T} 1, \mathrm{~T} 2, \mathrm{~T} 3, \mathrm{~T} 4$ and $\mathrm{T} 5$ in a Complete Randomized Design (CRD). Each treatment was replicated six times and there were 10 birds in each replicate.

\section{Treatment Rations}

Three concentrations of protease were added to the basal feed mixture and treatments were as follows;

Treatment 1: Recommended level of crude protein (CP) and amino acids (AA) concentration (Positive control)

Treatment 2: Level of CP and AA reduced by 5\% (Negative control)

Treatment 3: Negative control $+300 \mathrm{~g} \mathrm{t}^{-1}$ of protease

Treatment 4: Negative control $+400 \mathrm{~g} \mathrm{t}^{-1}$ of protease

Treatment 5: Negative control $+500 \mathrm{~g} \mathrm{t}^{-1}$ of protease

\section{Feed Mixing}

Feed rations were mixed according to the National Research Council (NRC) recommendations (NRC 1994), and the composition of each is presented in supplementary table 1, 2 and 3. The floor was cleaned to avoid contamination of any foreign materials. Macro and microingredients were weighed and mixed using a shovel, while mixing, vegetable oil. Finally, treatment additives were mixed. For the booster, starter and finisher period, $150 \mathrm{~kg}$, $750 \mathrm{~kg}, 1000 \mathrm{~kg}$ of feeds were prepared, respectively. Prepared rations were allocated to each pen and stored in labelled bags until feeding.

\section{Feeding Management}

Rations were offered in 3 feeding phases; broiler booster (day 8 to day 14), broiler starter (day 15 to day 28) and broiler finisher (day 29 to day 42). The rations and clean drinking water were provided ad libitum throughout the experimental period. General feeding regime of day 1 to day 7 was practised following VRI recommendations (Department of Animal Production and Health 2014). The treatment rations were provided from day 8 to 42 .

\section{Broiler Management Practices}

Day-old chicks were introduced to preheated brooder pens and brooded up to seven days. Electrical bulbs were used as heat sources and paddy husk was used as litter material. Chicks were introduced on the paper layer. Just after the introduction of chicks to pens, glucose and vitamins were supplied with drinking water, and vitamin supplement was provided continuously up to day seven. 


\section{$\mathrm{NH}_{3}$ Emission from Litter}

Amount of ammonia emitted from the litter was measured for each replicate weekly, using ammonia estimating machine (ADKS-1NH3, China).

\section{Slaughtering of Birds}

After 42 days of the growing period, two birds were randomly selected from each pen and weighed. Birds were slaughtered and bled. Feathers were removed with the skin. The digestive tract, respiratory tract, heart, and liver were removed and gall bladder was peeled away. Gizzard was cleaned and the inner layer was removed. Breast, thighs, and drumsticks with bone were cut and weighed. The weight of the internal organs; liver, gizzard, and heart were measured and expressed as a percentage of carcass weight.

\section{Chemical Analysis of Feed Samples}

Feed samples (100 g) were collected randomly after the mixing of feeds and ground to a fine powder. Then samples were stored in bags until the analysis. Experimental rations were analysed to determine moisture, crude protein (CP), crude fibre (CF), crude fat (EE) and ash, following the standard methods described by AOAC (2003).

\section{Serum Lipid Profile}

Blood samples were collected to plain sterilized tubes from one randomly selected fasting bird from each replicate at day 42. Immediately, the serum was separated at $1500 \mathrm{rpm}$ for $20 \mathrm{~min}$ using centrifugation (C0060, USA). Then, samples were stored in $20^{\circ} \mathrm{C}$ until further analysis. The serum samples were tested for total cholesterol, high-density lipoproteins (HDL), triglycerides (TAG) and low-density lipoproteins (LDL) using a commercial kit $(02160$ MAIZY, France) and a spectrophotometer (Uvd 2960, USA).

\section{Meat Quality Parameters}

Meat samples were taken from the breast area and stored in $-20^{\circ} \mathrm{C}$. Proximate analysis was done according to the AOAC methods (AOAC 2003).

For $\mathrm{pH}$ measurement, $1 \mathrm{~g}$ of meat sample from each replicate was taken, thawed for 30 min and blended with $9 \mathrm{~mL}$ of distilled water. Samples were filtered (Whatman- No. 4) and $\mathrm{pH}$ of filtrates was determined using a $\mathrm{pH}$ meter (E-08328 ALELLA, Barcelona).

Meat samples were cut into cubes $(2.0 \pm 0.10$

g) to measure the water holding capacity (WHC). Those were carefully placed between 2 pieces of filter papers (Whatman- No. 4) 
and left under a $10 \mathrm{~kg}$ weight for $5 \mathrm{~min}$ separately. After recording the final weight of each sample, WHC was calculated using equation 1 ;

Equation 1

$W H C(\%)=100-\left[\frac{(W i-W f) \times 100}{W i}\right]$

where $W_{i}$ and $W_{f}$ were the initial and final weights of the sample, respectively.

One sample for each replicate was used to evaluate the colour values at the dorsal surface of the intact skinless breast muscles using a colourimeter (CR 10 plus, Konica Minolta, Japan). The values of lightness ( $\mathrm{L}^{*}$ ), redness $\left(a^{*}\right)$, and yellowness $\left(b^{*}\right)$ were obtained at 3 sites on the same sample.

\section{Data Collection and Calculations}

Amount of feed given and remained per pen were measured and feed intake was calculated daily throughout the study period (Eq. 2). Body weight was measured weekly and weight gain and feed conversion ratio (FCR) were calculated (Eq. 3). Live weight and carcass weights were recorded and dressing percentage was calculated (Eq. 4). The weight of internal organs (liver, gizzard, and heart) were taken and expressed as a percentage of the carcass weight.

Equation 2

Feed intake $(g)=$ Given feed $(g)-$ Remain feed $(g)$
Equation 3

Feed conversion ratio $=\frac{\text { Feed intake }(\mathrm{kg})}{\text { Live weight gain }(\mathrm{kg})}$ Equation 4

Dressing percentage $(\%)=\frac{\text { Carcass weight }(\mathrm{kg})}{\text { Live weight }(\mathrm{kg})} \times 100$

The feed cost for different treatments was recorded throughout the study period. Feed intake per bird during the study period was calculated. The data were used to obtain the cost of feed per kg of live weight (Eq. 5) and carcass weight (Eq. 6)of the bird.

Equation 5

Cost of feed per $\mathrm{kg}$ of live weight $(\mathrm{Rs} / \mathrm{kg})=\frac{\text { Cost of feed per bird }}{\text { Live weight of a bird }}$

Equation 6

Cost of feed per $\mathrm{kg}$ of carcass weight $(\mathrm{Rs} / \mathrm{kg})=\frac{\text { Cost of feed per bird }}{\text { Carcass weight of a bird }}$

\section{Data Analysis}

Weight gain, feed intake, FCR, dressing percentage of birds, serum lipid profile, proximate composition of the meat samples and feed cost were analysed using the Analysis of Variance (ANOVA) procedure of Statistical Software for Data Analysis (SAS), Ver. 9.0 (SAS 2002). Mean separation was done by Turkey's Standardized Range Test (TSRT). Statistical significance was declared at $p<0.05$. 


\section{Results and Discussion}

\section{Feed Intake}

Effect of treatments on feed intake, weight gain and FCR of broilers fed with different rations supplemented with protease enzyme are presented in Table 1, 2 \& 3, respectively.

There were significant differences $(p<0.05)$ in feed intake of broilers fed with different treatment rations during booster period (from day 8 to 14), starter period (from day 15 - 28) and whole study period (from day 8 day 42) (Table 1). However, there was no significant difference $(p>0.05)$ in feed intake of birds during the finisher period (from day 29 - 42). During booster period, feed intake of birds fed with T1 was significantly higher $(p<0.05)$ compared to birds fed with treatment 2, 3 and 5. However, during the starter period and from day 36 to day 42 birds fed with T3 recorded significantly $(p<0.05)$ higher feed intake. Similar observations were recorded during the total study period.
The results are also in confirmation with the results of Angel et al. (2011). They showed that when Ross 708 broilers fed with monocomponent protease enzyme supplementation $(75,000$ protease units per g) to a corn-soy meal containing positive control ration (22.5\%) and low CP (20.5\%) ration, there is a positive influence on feed consumption from day 7 to day 22. Further, Law et al. (2018) stated that there were no significant CP $\times$ protease interactions for feed intake except feed intake during day 29 to 35 for birds fed with low protein rations. Moreover, they found feed intake was not affected by the enzyme inclusion during $2^{\text {nd }}$ and $3^{\text {rd }}$ weeks of age, except during the $1^{\text {st }}$ week. However, Ajayi (2015) showed that feed intake of birds significantly decreased with inclusion of different levels of protease to the basal ration formulated with $12.5 \%$, $14.4 \%$ and $20 \%$ CP levels with similar metabolisable energy level. 
Table 1: Average feed intake of broilers fed different rations supplemented with protease enzyme

\begin{tabular}{|c|c|c|c|c|c|c|c|}
\hline \multirow{2}{*}{ Period } & \multicolumn{5}{|c|}{ Feed intake (g/bird) in different treatments* } & \multirow{2}{*}{ P-value } & \multirow{2}{*}{ SE } \\
\hline & 1 & 2 & 3 & 4 & 5 & & \\
\hline Day $8-14$ & $437^{a}$ & $429^{b}$ & $430^{\mathrm{b}}$ & $434^{\mathrm{ab}}$ & $427 \mathrm{~b}$ & 0.03 & 2.42 \\
\hline Day $15-21$ & $840^{\mathrm{d}}$ & $888^{c}$ & $976^{\mathrm{a}}$ & $976^{\mathrm{a}}$ & $933^{\mathrm{b}}$ & 0.00 & 0.67 \\
\hline Day $22-28$ & $1104 \mathrm{e}$ & $1204^{a}$ & $1177^{b}$ & $1138^{c}$ & $1132^{\mathrm{d}}$ & 0.00 & 0.52 \\
\hline Day $29-35$ & 1203 & 1204 & 1304 & 1220 & 1194 & 0.68 & 59.56 \\
\hline Day $36-42$ & $1094^{d}$ & $1203^{\mathrm{bc}}$ & $1228^{a}$ & $1207 \mathrm{~b}$ & $1189^{c}$ & 0.00 & 5.16 \\
\hline Day 15 - 28 & $1944^{\mathrm{e}}$ & $2091^{c}$ & $2153^{\mathrm{a}}$ & $2114^{b}$ & $2064^{d}$ & 0.00 & 0.93 \\
\hline Day $29-42$ & 2297 & 2407 & 2532 & 2427 & 2381 & 0.13 & 60.44 \\
\hline Day $8-42$ & $4677^{c}$ & $4926^{b}$ & $5113^{a}$ & $4974^{\mathrm{ab}}$ & $4871^{b}$ & 0.00 & 61.13 \\
\hline
\end{tabular}

a, b, $\mathrm{c}$ means within the same row with different superscripts are significantly different $(p<0.05)$.

${ }^{*}$ The treatments were, $\mathrm{T}_{1}$ = positive control (recommended CP level), $\mathrm{T}_{2}=$ negative control (level of CP reduced by $5 \%$ ), $\mathrm{T}_{3}=$ negative control $+300 \mathrm{~g} \mathrm{t}^{-1}$ protease, $\mathrm{T}_{4}=$ negative control $+400 \mathrm{~g} \mathrm{t}^{-1}$ protease and $\mathrm{T}_{5}=$ negative control $+500 \mathrm{~g} \mathrm{t}^{-1}$ proteases.

\section{Weight Gain}

Table 2: Average weight gain of broilers fed different rations supplemented with protease enzyme

\begin{tabular}{lccccccc}
\hline & \multicolumn{5}{c}{ Peight gain (g/bird) in different treatments } & P-value & SE \\
\cline { 2 - 6 } & $\mathbf{1}$ & $\mathbf{2}$ & $\mathbf{3}$ & $\mathbf{4}$ & $\mathbf{5}$ & & \\
\hline Day 8 - 14 & $295^{\mathrm{ab}}$ & $271^{\mathrm{c}}$ & $280^{\mathrm{bc}}$ & $281^{\mathrm{abc}}$ & $303^{\mathrm{a}}$ & 0.04 & 7.43 \\
Day 15 - 21 & 484 & 452 & 499 & 503 & 479 & 0.43 & 20.36 \\
Day 2 2 - 28 & 477 & 531 & 500 & 461 & 514 & 0.25 & 23.39 \\
Day 29 - 35 & 601 & 669 & 623 & 628 & 643 & 0.86 & 45.11 \\
Day 36 - 42 & $597^{\mathrm{b}}$ & $460^{\mathrm{c}}$ & $549^{\mathrm{bc}}$ & $517^{\mathrm{bc}}$ & $726^{\mathrm{a}}$ & 0.00 & 43.38 \\
\hline Day 15 - 28 & 960 & 982 & 999 & 963 & 992 & 0.50 & 18.62 \\
Day 29 - 42 & $1198^{\mathrm{b}}$ & $1129^{\mathrm{b}}$ & $1172^{\mathrm{b}}$ & $1145^{\mathrm{b}}$ & $1367^{\mathrm{a}}$ & 0.04 & 57.68 \\
Day 8 - 42 & $2451^{\mathrm{b}}$ & $2380^{\mathrm{b}}$ & $2449^{\mathrm{b}}$ & $2388^{\mathrm{b}}$ & $2663^{\mathrm{a}}$ & 0.00 & 53.58 \\
\hline
\end{tabular}

$\mathrm{a}, \mathrm{b}, \mathrm{c}$ means within the same row with different superscripts are significantly different $(p<0.05)$.

${ }^{*}$ The treatments were, $\mathrm{T}_{1}=$ positive control (recommended CP level), $\mathrm{T}_{2}=$ negative control (level of CP reduced by $5 \%$ ), $\mathrm{T}_{3}=$ negative control $+300 \mathrm{~g} \mathrm{t}^{-1}$ protease, $\mathrm{T}_{4}=$ negative control $+400 \mathrm{~g} \mathrm{t}^{-1}$ protease and $\mathrm{T}_{5}=$ negative control $+500 \mathrm{~g} \mathrm{t}^{-1}$ protease.

The body weight gain was significantly from day $8-14$, day $36-42$, day $29-42$ $(p<0.05)$ different among the treatments (finisher period) and day 8 - 42 (whole study 
period) (Table 2). The birds fed with $500 \mathrm{~g} \mathrm{t}^{-1}$ of protease added to $5 \%$ reduced $\mathrm{CP}$ ration (T5) had the highest body weight gain in day 36 - 42, day 29 - 42 and day 8 - 42.

The present study is also in agreement with the study of Fosnaught and Odetellah (2005) who experimented on broilers by adding Versazyme protease enzyme at $0.1 \%$ to cornsoybean meal based rations. Their results revealed that body weight gain of birds at 21 , 35 and 42 days of age was improved by the addition of Versazyme protease enzyme. Further, Mohammadigheisar and Kim (2018) showed that supplementing low CP diets with protease alleviated the negative effects of lowering dietary CP on body weight gain during day 1 - 2. Zakaria et al. (2010) also reported higher weight gains in Lohmann broilers at 42 days of age fed with rations supplemented with enzyme mixture (protease, alpha-amylase, pectinase, phytase and cellulose). Law et al. (2018) also observed improved weight gains in broilers fed with protease supplementation.

\section{Feed Conversion Ratio}

The FCR was significantly $(p<0.05)$ different among the treatments from day $36-42$, day 15 - 28 and day 8 - 42 periods (Table 3).

The results are also in confirmation with results of Café et al. (2002). As per the result of the research, in commercial broilers fed with rations (nutritionally complete broiler ration based on the corn-soybean meal) supplementing Avizyme at $0.1 \%$ at 35 and 49 days of age showed a non-significant effect on FCR. However, they observed FCR of broilers had a significant effect at 16 days and 42 days of age.

Table 3: Average feed conversion ratio of broilers fed different rations supplemented with protease enzyme

\begin{tabular}{|c|c|c|c|c|c|c|c|}
\hline \multirow{2}{*}{ Period } & \multicolumn{5}{|c|}{ FCR in different treatments* } & \multirow{2}{*}{ P-value } & \multirow{2}{*}{ SE } \\
\hline & 1 & 2 & 3 & 4 & 5 & & \\
\hline Day $8-14$ & 1.51 & 1.60 & 1.55 & 1.55 & 1.42 & 0.07 & 0.05 \\
\hline Day $15-21$ & 1.77 & 1.98 & 1.97 & 1.96 & 1.98 & 0.38 & 0.09 \\
\hline Day $22-28$ & 2.34 & 2.3 & 2.38 & 2.5 & 2.24 & 0.53 & 0.11 \\
\hline Day $29-35$ & 2.11 & 1.87 & 2.13 & 1.96 & 1.9 & 0.74 & 0.18 \\
\hline Day $36-42$ & $1.85^{b}$ & $2.66^{\mathrm{a}}$ & $2.32^{\mathrm{ab}}$ & $2.67 \mathrm{a}$ & $1.65^{b}$ & 0.01 & 0.24 \\
\hline Day $15-28$ & $2.03^{b}$ & $2.14^{\mathrm{ab}}$ & $2.15^{\mathrm{a}}$ & $2.19^{a}$ & $2.08^{\mathrm{ab}}$ & 0.04 & 0.04 \\
\hline Day $29-42$ & 1.95 & 2.16 & 2.2 & 2.17 & 1.75 & 0.09 & 0.13 \\
\hline Day 8 - 42 & $1.92^{b c}$ & $2.08^{\mathrm{ab}}$ & $2.1^{\mathrm{a}}$ & $2.1^{\mathrm{a}}$ & $1.84 \mathrm{c}$ & 0.00 & 0.06 \\
\hline
\end{tabular}

a,b,c means within the same row with different superscripts are significantly different $(p<0.05)$.

${ }^{*}$ The treatments were, $\mathrm{T}_{1}=$ positive control (recommended CP level), $\mathrm{T}_{2}=$ negative control (level of CP reduced by $5 \%$ ), $\mathrm{T}_{3}=$ negative control $+300 \mathrm{~g} \mathrm{t}^{-1}$ protease, $\mathrm{T}_{4}=$ negative control $+400 \mathrm{~g} \mathrm{t}^{-1}$ protease and $\mathrm{T}_{5}=$ negative control $+500 \mathrm{~g} \mathrm{t}^{-1}$ protease. 
As shown in Table 2, during day 8 - day 14, weight gain was similar in control, T3, T4 and T5. It has been suggested that the underdeveloped intestines of the birds at starter period are unable to produce sufficient amounts of digestive secretions. Hence, supplementation of the rations with enzymes makes them utilize the nutrients efficiently and perform better in terms of growth performances (Dosković et al. 2013).

Further, as shown in Table 2 and 3, the results indicate that the feed efficiency of the broilers was depressed with a reduction of the crude protein content of their ration. Moreover, feed utilization was enhanced with protease supplementation in the ration. Better feed conversion and a higher weight gain were obtained with T5, suggesting that the higher enzyme dosage allows birds to utilize the nutrients efficiently without causing any dietary imbalances.

\section{Carcass Characteristics}

The live weights were significantly $(p<0.05)$ different among the treatments at day 42 and the highest live weight was recorded in birds supplemented with T5 (Table 4). However, carcass weight and dressing percentage were not significantly $(p>0.05)$ different among the treatments (Table 4).

These results are in agreement with Freitas et al. (2011). Also, Yadav and Sah (2005) studied the effect of supplementation of acid protease to corn-soybean meal based diets at $0 \%, 0.05 \%, 0.075 \%$ and $0.1 \%$ to control diet (18.5\% CP) and reduced CP $\operatorname{diet}(17.5 \% \mathrm{CP})$. However, they showed that there was no effect of supplementation of protease enzyme on dressing percentage of broilers.

Table 4: Carcass characteristics of broilers fed different rations supplemented with protease enzyme

\begin{tabular}{|c|c|c|c|c|c|c|c|}
\hline \multirow{2}{*}{ Parameter } & \multicolumn{5}{|c|}{ Treatment* } & \multirow{2}{*}{ P-value } & \multirow[b]{2}{*}{ SE } \\
\hline & 1 & 2 & 3 & 4 & 5 & & \\
\hline Live weight (kg) & $2.64^{b}$ & $2.60^{\mathrm{b}}$ & $2.65^{b}$ & $2.52^{b}$ & $2.86^{\mathrm{a}}$ & 0.02 & 0.07 \\
\hline Dressing percentage (\%) & 68.41 & 73.64 & 62.34 & 64.14 & 66.43 & 0.10 & 3.00 \\
\hline \multicolumn{8}{|c|}{ Carcass cuts ( $\%$ carcass weight) } \\
\hline Brest & $45.4^{\mathrm{a}}$ & $38.68^{b}$ & $39.84^{b}$ & $37.60^{\mathrm{b}}$ & $36.51^{b}$ & 0.00 & 1.70 \\
\hline Wings & 8.26 & 6.17 & 8.84 & 8.93 & 7.47 & 0.22 & 0.92 \\
\hline Thighs & $29.2^{\mathrm{bc}}$ & $26.92^{c}$ & $37.05^{a}$ & $32.45^{\mathrm{abc}}$ & $34.92^{\mathrm{ab}}$ & 0.02 & 2.28 \\
\hline \multicolumn{8}{|c|}{ Internal organs (\% carcass weight) } \\
\hline Liver & 3.29 & 3.32 & 3.28 & 3.39 & 3.24 & 0.98 & 0.18 \\
\hline Heart & 0.89 & 1.15 & 0.92 & 1.29 & 0.84 & 0.21 & 0.18 \\
\hline
\end{tabular}

a, b, c means within the same row with different superscripts are significantly different $(p<0.05)$.

${ }^{*}$ The treatments were, $\mathrm{T}_{1}=$ positive control (recommended CP level), $\mathrm{T}_{2}=$ negative control (level of CP reduced by $5 \%$ ), $\mathrm{T}_{3}=$ negative control $+300 \mathrm{~g} \mathrm{t}^{-1}$ protease, $\mathrm{T}_{4}=$ negative control $+400 \mathrm{~g} \mathrm{t}^{-1}$ protease and $\mathrm{T}_{5}=$ negative control $+500 \mathrm{~g} \mathrm{t}^{-1}$ protease 
The results were contradictory to the findings of Espino et al. (2000) who observed a slight increase in the dressing percentage of broilers fed rations containing a mixture of enzymes.

Further, Ajayi (2015) reported improved dressing percentages with protease inclusion compared to the birds fed with control ration without protease. These differences may occur due to the variation of broiler diets, enzymes and their level of inclusions.

There was no significant $(p>0.05)$ effect of supplementation of protease enzyme on giblet percentage of commercial broilers (Table 4). However, the highest and the lowest liver and heart percentages were recorded in birds fed with T4 and T5 rations, respectively. Further, the highest and the lowest gizzard percentage were recorded in birds fed with $300 \mathrm{~g} \mathrm{t}^{-1}$ and $500 \mathrm{~g} \mathrm{t}^{-1}$ of protease added to $5 \%$ reduce $\mathrm{CP}$ rations (T3 and T5).

Zakaria et al. (2010) reported that multienzyme (protease, alpha-amylase, pectinase, phytase and cellulase) supplementation at $250,500,750 \mathrm{~g} \mathrm{t}^{-1}$ of feed did not affect giblet weights in Lohmann broilers at 42 days of age, which confirms the results of the present study. Further, Ndazigaruye (2019) showed that the protease enzyme increased the relative liver weight of broilers at 21 days of age, but disappears the effect at 35 days of age.

\section{Meat Quality Parameter}

Meat quality parameters of the present study were not significantly $(p>0.05)$ different among the treatments (Table 5).

The present results are in agreement with Yadav and Sah (2005). Accordingly, male broilers fed with supplementing acid protease to corn-soybean meal based diets at $0 \%, 0.05 \%, 0.075 \%$ and $0.1 \%$ to control diet (18.5\% CP) and reduced CP diet (17.5\% CP) from day 0 to 42 did not show a difference in crude protein, crude fat and crude ash percentages. Further, in the study of Yang et al. (2010), Arbor Acres male broilers were fed by supplementing multi-enzyme additive containing amylase, protease, and xylanase in rations for 36 days. There was no difference in dry matter and crude protein in meat as compared with birds fed with lower enzyme diet or the control diet.

\section{Blood Serum Parameters}

Blood serum parameters were not significantly $(p>0.05)$ different among the treatments (Table 6). The results in this study are in agreement with the findings of Zakaria et al. (2010). As the results, the 
Lohmann broilers supplemented with multienzyme (protease, alma amylase, pectinase, phytase and cellulase) at $250,500,750 \mathrm{~g} \mathrm{t}^{-1}$ of feed showed no significant effect on blood serum parameters. Further, Ndazigaruye

Table 5: Meat quality parameter of broilers fed different rations supplemented with protease enzymes

\begin{tabular}{lccccccc}
\hline \multirow{2}{*}{ Quality Parameter } & \multicolumn{9}{c}{ Treatment $^{*}$} & \multirow{2}{*}{ P-value } & \multirow{2}{*}{ SE } \\
\cline { 2 - 6 } & $\mathbf{1}$ & $\mathbf{2}$ & $\mathbf{3}$ & $\mathbf{4}$ & $\mathbf{5}$ & & 0.45 \\
Dry matter \% & 24.69 & 25.18 & 24.59 & 25.76 & 23.97 & 0.09 & 0.62 \\
Crude protein \% & 9.49 & 11.08 & 10.42 & 11.64 & 9.66 & 0.09 & 0.15 \\
Ash \% & 4.25 & 4.25 & 4.19 & 4.09 & 4.28 & 0.89 & 0.11 \\
Ether extract \% & 3.24 & 3.21 & 3.35 & 3.43 & 3.48 & 0.30 & 1.69 \\
Colour (L*) & 51.08 & 51.17 & 53.68 & 49.93 & 49.96 & 0.52 & 0.04 \\
pH & 5.74 & 5.92 & 5.77 & 5.82 & 5.84 & 0.05 & 4.24 \\
WHC \% & 67.52 & 56.9 & 65.5 & 65.59 & 65.55 & 0.44 & \\
\hline
\end{tabular}

${ }^{*}$ The treatments were, $\mathrm{T} 1=$ positive control (recommended CP level), $\mathrm{T} 2=$ negative control (level of CP reduced by $5 \%), \mathrm{T} 3=$ negative control $+300 \mathrm{~g} \mathrm{t}^{-1}$ protease, $\mathrm{T} 4=$ negative control $+400 \mathrm{~g} \mathrm{t}^{-1}$ protease and $\mathrm{T} 5=$ negative control + $500 \mathrm{~g} \mathrm{t}^{-1}$ protease.

Table 6: Blood serum parameters of broilers fed different rations supplemented with protease enzyme

\begin{tabular}{|c|c|c|c|c|c|c|c|}
\hline \multirow{2}{*}{$\begin{array}{l}\text { Parameter } \\
\text { (mg/dL) }\end{array}$} & \multicolumn{5}{|c|}{ Treatment $^{*}$} & \multirow{2}{*}{ P-value } & \multirow{2}{*}{ SE } \\
\hline & 1 & 2 & 3 & 4 & 5 & & \\
\hline Triglyceride & 78.30 & 75.80 & 74.79 & 70.35 & 67.15 & 0.25 & 3.76 \\
\hline Total cholesterol & 155.82 & 147.04 & 147.62 & 142.72 & 145.20 & 0.10 & 3.36 \\
\hline HDL & 71.39 & 72.18 & 66.78 & 63.57 & 62.79 & 0.33 & 3.95 \\
\hline LDL & 68.77 & 59.70 & 65.66 & 62.78 & 67.65 & 0.77 & 5.56 \\
\hline
\end{tabular}

${ }^{*}$ The treatments were, $\mathrm{T} 1=$ positive control (recommended CP level), $\mathrm{T} 2$ = negative control (level of CP reduced by $5 \%), \mathrm{T} 3=$ negative control $+300 \mathrm{~g} \mathrm{t}^{-1}$ protease, $\mathrm{T} 4=$ negative control $+400 \mathrm{~g} \mathrm{t}^{-1}$ protease and $\mathrm{T} 5=$ negative control + $500 \mathrm{~g}^{-1}$ protease.

\section{$\mathrm{NH}_{3}$ Emission from Litter}

Ammonia emission from the litter was not significantly $(p>0.05)$ different among the treatments (Table 7). 
Table 7: $\mathrm{NH}_{3}$ emission of the litter of broilers fed different rations supplemented with protease enzyme

\begin{tabular}{ccccccccc}
\hline Parameter & \multicolumn{4}{c}{ Treatment $^{*}$} & \multicolumn{2}{c}{ P- } & SE \\
\cline { 2 - 7 } & $\mathbf{1}$ & $\mathbf{2}$ & $\mathbf{3}$ & $\mathbf{4}$ & $\mathbf{5}$ & value & \\
\hline $\mathrm{NH}_{3}$ in litter ppm & 6.52 & 6.43 & 6.51 & 6.38 & 6.36 & 0.61 & 0.08 \\
\hline
\end{tabular}

${ }^{*}$ The treatments were, $\mathrm{T}_{1}$ = positive control (recommended CP level), $\mathrm{T}_{2}=$ negative control (level of CP reduced by $5 \%$ ), $\mathrm{T}_{3}=$ negative control $+300 \mathrm{~g} \mathrm{t}^{-1}$ protease, $\mathrm{T}_{4}=$ negative control $+400 \mathrm{~g} \mathrm{t}^{-1}$ protease and $\mathrm{T}_{5}=$ negative control $+500 \mathrm{~g} \mathrm{t}^{-1}$ protease.

\section{Cost Analysis}

Feed cost per kg of live weight and feed cost per $\mathrm{kg}$ of the saleable carcass were significantly $(p<0.05)$ different among the treatments (Table 8). The highest feed cost per kg of live weight and saleable carcass weight were recorded in T4. The lowest feed cost per kg of live weight and saleable carcass weight were recorded in T5. The production cost per $\mathrm{kg}$ of live weight at 42 days of age and production cost per kg of carcass weight due to supplementation of protease enzyme were similar compared to non-supplemented rations (positive and negative controls) with $5 \%$ protease enzyme supplemented ration. Similarly, Yadav and Sah (2005) analysed the effect of protease supplementation on production costs and the authors received the highest income from the rations supplemented with $0.075 \%$ protease. Therefore, protease supplementation profoundly decreased the production cost as compared to the basal diet.

Table 8: Cost analysis of broilers fed different rations supplemented with protease enzyme

\begin{tabular}{|c|c|c|c|c|c|c|c|}
\hline \multirow{2}{*}{ Parameter } & \multicolumn{5}{|c|}{ Treatment $^{*}$} & \multirow{2}{*}{ P-value } & \multirow{2}{*}{ SE } \\
\hline & 1 & 2 & 3 & 4 & 5 & & \\
\hline $\begin{array}{l}\text { Feed cost per kg of live } \\
\text { weight (LKR) }\end{array}$ & $169.34^{\mathrm{bc}}$ & $180.40^{\mathrm{ab}}$ & $184.47^{\mathrm{ab}}$ & $188.37^{a}$ & $162.06^{c}$ & 0.01 & 5.73 \\
\hline $\begin{array}{l}\text { Feed cost per kg of } \\
\text { saleable carcass } \\
(\mathrm{LKR})\end{array}$ & $249.89^{b}$ & $250.48^{b}$ & $297.97^{a}$ & $295.70^{a}$ & $244.03^{\mathrm{b}}$ & 0.02 & 14.26 \\
\hline
\end{tabular}

a, b, c means within the same row with different superscripts are significantly different $(p<0.05)$.

${ }^{*}$ The treatments were, $\mathrm{T}_{1}=$ positive control (recommended CP level), $\mathrm{T}_{2}=$ negative control (level of CP reduced by $5 \%$ ), $\mathrm{T}_{3}=$ negative control $+300 \mathrm{~g} \mathrm{t}^{-1}$ protease, $\mathrm{T}_{4}=$ negative control $+400 \mathrm{~g} \mathrm{t}^{-1}$ protease and $\mathrm{T}_{5}=$ negative control $+500 \mathrm{~g} \mathrm{t}^{-1}$ protease

\section{Conclusions}

Feeding $500 \mathrm{~g} \mathrm{t}^{-1}$ of protease with $5 \%$ crude protein reduced ration is a better solution to improve protein digestibility without interfering the growth performances of broilers with lower cost and maximum economic benefits. 
Conflicts of Interest:The authors have no conflicts of interest regarding this publication.

\section{References}

Ajayi H I (2015) A effect of protease supplementation on performance and carcass weights of broiler chickens fed low protein diets. Niger J Agric Food Environ 11(1):2932.

Angel C R, Saylor W, Vieira S L, Ward N (2011) Effects of mono component Protease on performance and protein utilization in 7to 22-day-old broiler chickens. Poult Sci 90(10):2281-2286. DOI: 10.3382/ps.201101482

Anon (2018) Poultry production outlook positive but with slowing growth, Available on:

https://www.wattagnet.com/articles/25044 -poultry-production outlook-positive-butwith. Retrieved on: 02 November 2018 slowing-growth

AOAC (2003) Official methods of analysis (18 $8^{\text {th }}$ edition). Association of official analytical chemists, Washington DC, U.S.A.

Bedford M (2009) The use of enzymes to improve the nutritive value of co-products.
Recent Adv in Anim Nutr, 1:339-348. DOI: 10.5661/recadv-08-339.

Bessei W (2006) Welfare of broilers: a review. World's Poult. Sci. J 62(3):455-466. DOI:10.1017/S004393390600108.

Café M B, Borges C A, Fritts C A, Waldroup P W (2002) Avizyme improves performance of broilers fed corn-soybean meal-based diets. J Appl Poult Res 11(1):29-33.

DOI:10.1093/japr/11.1.29.

Cowieson A, Ravindran V (2008) Sensitivity of broiler starters to three doses of an enzyme cocktail in maize-based diets. $\mathrm{Br}$ Poult Sci 49(3): 340-346. DOI:10.1080/00071660802126669.

Department of Animal Production and Health (2014) Annual report. Available on : www.daph.gov.lk/web. Retrieved on: 28 May 2017.

Dosković V, Bogosavljević-Bosković S, Pavlovski Z, Milošević B, Škrbić Z, Rakonjac S, Petričević V (2013) Enzymes in broiler diets with special reference to protease. World's Poult Sci J 69(2):343-360. DOI: $10.1017 /$ S0043933913000342.

Espino T M, Luis E S, Sapin A B, Tambalo R D, Unida F B (2000) Acid protease from Monascus sp. Biotech 3064 and other 
microbial enzymes and feed additives in broiler diets. Proceedings of the 29th Annual Convention. Philippines Society for Microbiology Inc. 121-133.

Fosnaught M, Odetellah N (2005) Effect of Versayme (TM) and dietary protein levels oil growth performance of broilers using industry-based criteria for evaluation. Poult Sci 84: 123-124.

Freitas D M, Vieira S L, Angel C R, Favero A, Maiorka A (2011) Performance and nutrient utilization of broilers fed diets supplemented with a novel mono-component Protease. J Appl Poult Res 20(3):322-334. DOI:10.3382/japr.2010-00295.

Ghazi S, Rooke J A, Galbraith H, Bedford M R (2002) The potential for the improvement of the nutritive value of soya-bean meal by different proteases in broiler chicks and broiler cockerels. Br Poult Sci 43(1):70-77. DOI:10.1080/00071660120109935.

Gunal M, Yayli G, Kaya O, Karahan N, Sulak O (2006) The effects of antibiotic growth promoter, probiotic or organic acid supplementation on performance, intestinal microflora and tissue of broilers. J Poult Sci 5(2):149-155. DOI: 10.3923/ijps.2006.149.155.
Hedstrom L (2002) Serine Protease Mechanism and Specificity. Chem Rev 102(12): 4501-4524.

DOI:10.1021/cr000033x.

Law F L, Zulkifli I, Soleimani A F, Liang J B, Awad E A (2018) The effects of low-protein diets and protease supplementation on broiler chickens in a hot and humid tropical environment. Asian-Australas J Anim Sci 31(8):1291-1300. DOI:10.5713/ajas.17.0581.

Maidala A, Doma U D, Egbo L M (2013) Effects of different processing methods on the chemical composition and antinutritional factors of soybean. Pak J Nutr, 12(12):1057-1060.

DOI:10.3923/pjn.2013.1057.1060.

Mohammadigheisar M, Kim I H (2018) Addition of a protease tolow crude protein density diets of broiler chickens. J Appl Anim Res 46(1):1377-1381, DOI: 10.1080/09712119.2018.1512862.

Moughan (2014) Dietary protein and amino acids, consideration of the undigestible fraction, Poult Sci, 93(9):2400-2410. DOI: 10.3382/ps.2013-03861.

Ndazigaruye G, Kim D H, Kang C W, Kang K R, Joo Y J, Lee S R, Lee K W (2019) Effects of low-protein diets and exogenous protease on growth performance, carcass traits, intestinal 
morphology, cecal volatile fatty acids and serum parameters in broilers. Animals, 9(5): 226. DOI:10.3390/ani9050226

NRC (1994) Nutrient requirements of poultry (9 $9^{\text {th }}$ edn). National Academy Press, Washington D.C., U.S.A.

OECD-FAO (2010) OECD-FOA Agricultural Outlook 2018-2027, Foof and Agricultural Organization of United Nations, http://dx.doi.org/10.1787/agr_outlook2018-en.

SAS (2002) Statistical Analyses System. Users Guide Statistics. SAS Institute Inc. Cary, North Carolina, U.S.A.

Yadav J L, Sah R A (2005) Supplementation of corn-soybean based broiler's diets with different levels of acid protease. J Inst Agric Anim Sci 26: 65-70.
Yang Z B, Yang W R, Jinang S Z, Zhang G G, Zhang Q Q, Siow K C (2010) Effects of a thermo-tolerant multi-enzyme product on nutrient and energy utilization of broilers fed mash or crumbled corn-soybean meal diets. J Appl Poult Res 19(1):38-45. DOI: 10.3382/japr.2009-00075.

Zakaria H A H, Mohammad A R J, Ishmais M A B (2010) The influence of supplemental multi-enzyme feed additive on the performance, carcass characteristics and meat quality traits of broiler chickens. Int J Poult Sci 9(2):126-133. DOI: 10.3923/ijps.2010.126.133.

D0I:10.3126/jiaas.v26i0.613. 
Supplementary Table 1: Composition of chick booster feed mixed with different protease concentration

\begin{tabular}{|c|c|c|c|c|c|}
\hline \multirow{2}{*}{ Ingredient \% } & \multicolumn{5}{|c|}{ Treatments* } \\
\hline & 1 & 2 & 3 & 4 & 5 \\
\hline Broken rice & 56.22 & 59.17 & 59.14 & 59.13 & 59.12 \\
\hline DDGS & 5.5 & 5.5 & 5.5 & 5.5 & 5.5 \\
\hline Vegetable fat & 1.4 & 1.1 & 1.1 & 1.1 & 1.1 \\
\hline Soybean meal & 25.5 & 23.2 & 23.2 & 23.2 & 23.2 \\
\hline Corn gluten meal & 2 & 2 & 2 & 2 & 2 \\
\hline Fish meal & 2.5 & 2 & 2 & 2 & 2 \\
\hline Meat \& bone meal & 4 & 4 & 4 & 4 & 4 \\
\hline DCP & 0.5 & 0.5 & 0.5 & 0.5 & 0.5 \\
\hline Limestone -powder & 0.82 & 0.95 & 0.95 & 0.95 & 0.95 \\
\hline Salt & 0.2 & 0.2 & 0.2 & 0.2 & 0.2 \\
\hline Sodium bicarbonate & 0.2 & 0.2 & 0.2 & 0.2 & 0.2 \\
\hline Choline chloride $60 \%$ & 0.1 & 0.1 & 0.1 & 0.1 & 0.1 \\
\hline L-lysine $98.5 \%$ & 0.225 & 0.245 & 0.245 & 0.245 & 0.245 \\
\hline DL-Methione $98.5 \%$ & 0.265 & 0.265 & 0.265 & 0.265 & 0.265 \\
\hline L-Threonine 99\% & 0.115 & 0.115 & 0.115 & 0.115 & 0.115 \\
\hline Toxin binder & 0.1 & 0.1 & 0.1 & 0.1 & 0.1 \\
\hline Phytase 5000 & 0.01 & 0.01 & 0.01 & 0.01 & 0.01 \\
\hline NutriMin CPM116 & 0.2 & 0.2 & 0.2 & 0.2 & 0.2 \\
\hline Vitamin MPV118 & 0.05 & 0.05 & 0.05 & 0.05 & 0.05 \\
\hline Salinomycin & 0.04 & 0.04 & 0.04 & 0.04 & 0.04 \\
\hline Probiotics-100 & 0.02 & 0.02 & 0.02 & 0.02 & 0.02 \\
\hline Protease & - & - & 0.03 & 0.04 & 0.05 \\
\hline Tributyrin- $45 \%$ & 0.035 & 0.035 & 0.035 & 0.035 & 0.035 \\
\hline
\end{tabular}

${ }^{*}$ The treatments were, $\mathrm{T}_{1}$ = positive control (recommended CP level), $\mathrm{T}_{2}=$ negative control (level of CP reduced by $5 \%$ ), $\mathrm{T}_{3}=$ negative control $+300 \mathrm{~g} \mathrm{t}^{-1}$ protease, $\mathrm{T}_{4}=$ negative control $+400 \mathrm{~g} \mathrm{t}^{-1}$ protease and $\mathrm{T}_{5}=$ negative control $+500 \mathrm{~g} \mathrm{t}^{-1}$ protease. 
Supplementary Table 2: Composition of starter feed mixed with different protease concentration

\begin{tabular}{|c|c|c|c|c|c|}
\hline \multirow{2}{*}{ Ingredient \% } & \multicolumn{5}{|c|}{ Treatments* } \\
\hline & 1 & 2 & 3 & 4 & 5 \\
\hline Broken rice & 55.035 & 58.2 & 58.17 & 58.16 & 58.15 \\
\hline Wheat shorts & 2 & 2 & 2 & 2 & 2 \\
\hline DDGS & 7 & 7 & 7 & 7 & 7 \\
\hline Vegetable fat & 2.4 & 2 & 2 & 2 & 2 \\
\hline Soybean meal & 23.75 & 21 & 21 & 21 & 21 \\
\hline Corn gluten meal & 2 & 2 & 2 & 2 & 2 \\
\hline Meat \& bone meal & 5 & 5 & 5 & 5 & 5 \\
\hline DCP & 0.45 & 0.45 & 0.45 & 0.45 & 0.45 \\
\hline Limestone -powder & 0.8 & 0.8 & 0.8 & 0.8 & 0.8 \\
\hline Salt & 0.25 & 0.25 & 0.25 & 0.25 & 0.25 \\
\hline Sodium bicarbonate & 0.22 & 0.22 & 0.22 & 0.22 & 0.22 \\
\hline Choline chloride $60 \%$ & 0.08 & 0.08 & 0.08 & 0.08 & 0.08 \\
\hline L-lysine $98.5 \%$ & 0.2 & 0.2 & 0.2 & 0.2 & 0.2 \\
\hline DL-Methione $98.5 \%$ & 0.25 & 0.235 & 0.235 & 0.235 & 0.235 \\
\hline L-Threonine 99\% & 0.125 & 0.125 & 0.125 & 0.125 & 0.125 \\
\hline Toxin Binder & 0.1 & 0.1 & 0.1 & 0.1 & 0.1 \\
\hline Phytase 5000 & 0.01 & 0.01 & 0.01 & 0.01 & 0.01 \\
\hline NutriMin CPM116 & 0.2 & 0.2 & 0.2 & 0.2 & 0.2 \\
\hline Vitamin MPV118 & 0.04 & 0.04 & 0.04 & 0.04 & 0.04 \\
\hline Protease & - & - & 0.03 & 0.04 & 0.05 \\
\hline Maduramycin 1\% & 0.04 & 0.04 & 0.04 & 0.04 & 0.04 \\
\hline Probiotics-100 & 0.015 & 0.015 & 0.015 & 0.015 & 0.015 \\
\hline Tributyrin- $45 \%$ & 0.035 & 0.035 & 0.035 & 0.035 & 0.035 \\
\hline
\end{tabular}

${ }^{*}$ The treatments were, $\mathrm{T}_{1}=$ positive control (recommended CP level), $\mathrm{T}_{2}=$ negative control (level of CP reduced by $5 \%), \mathrm{T}_{3}=$ negative control $+300 \mathrm{~g} \mathrm{t}^{-1}$ protease, $\mathrm{T}_{4}=$ negative control $+400 \mathrm{~g} \mathrm{t}^{-1}$ protease and $\mathrm{T}_{5}=$ negative control $+500 \mathrm{~g} \mathrm{t}^{-1}$ protease. 
Supplementary Table 3: Composition of finisher feed mixed with different protease concentration

\begin{tabular}{|c|c|c|c|c|c|}
\hline \multirow{2}{*}{ Ingredient \% } & \multicolumn{5}{|c|}{ Treatments* } \\
\hline & 1 & 2 & 3 & 4 & 5 \\
\hline Broken rice & 53.6 & 55.4 & 55.4 & 55.4 & 55.4 \\
\hline Rice polish & 5 & 5 & 5 & 5 & 5 \\
\hline DDGS & 10 & 10.2 & 10.2 & 10.2 & 10.2 \\
\hline Vegetable fat & 4.5 & 4.5 & 4.5 & 4.5 & 4.5 \\
\hline Soybean meal & 16.9 & 15.2 & 151.7 & 151.6 & 151.5 \\
\hline Corn gluten meal $60 \%$ & 2.5 & 2.01 & 2.01 & 2.01 & 2.01 \\
\hline Meat \& bone meal & 5 & 4.8 & 4.8 & 4.8 & 4.8 \\
\hline DCP & 0.3 & 0.4 & 0.4 & 0.4 & 0.4 \\
\hline Limestone -powder & 0.5 & 0.8 & 0.8 & 0.8 & 0.8 \\
\hline Salt & 0.25 & 0.25 & 0.25 & 0.25 & 0.25 \\
\hline Sodium bicarbonate & 0.25 & 0.25 & 0.25 & 0.25 & 0.25 \\
\hline Choline chloride $60 \%$ & 0.05 & 0.05 & 0.05 & 0.05 & 0.05 \\
\hline L-lysine $98.5 \%$ & 0.34 & 0.34 & 0.34 & 0.34 & 0.34 \\
\hline DL-Methione $98.5 \%$ & 0.26 & 0.25 & 0.25 & 0.25 & 0.25 \\
\hline L-Threonine 99\% & 0.115 & 0.115 & 0.115 & 0.115 & 0.115 \\
\hline Antioxidant & 0.02 & 0.02 & 0.02 & 0.02 & 0.02 \\
\hline Toxin Binder & 0.1 & 0.1 & 0.1 & 0.1 & 0.1 \\
\hline Phytase 5000 & 0.01 & 0.01 & 0.01 & 0.01 & 0.01 \\
\hline Protease & - & - & 0.03 & 0.04 & 0.05 \\
\hline NutriMin CPM116 & 0.2 & 0.2 & 0.2 & 0.2 & 0.2 \\
\hline Vitamin MPV118 & 0.035 & 0.035 & 0.035 & 0.035 & 0.035 \\
\hline Maduramycin 1\% & 0.05 & 0.05 & 0.05 & 0.05 & 0.05 \\
\hline Probiotics-100 & 0.02 & 0.02 & 0.02 & 0.02 & 0.02 \\
\hline
\end{tabular}

*The treatments were, $\mathrm{T}_{1}$ = positive control (recommended CP level), $\mathrm{T}_{2}=$ negative control (level of CP reduced by $5 \%$ ), $\mathrm{T}_{3}=$ negative control $+300 \mathrm{~g} \mathrm{t}^{-1}$ protease, $\mathrm{T}_{4}=$ negative control $+400 \mathrm{~g} \mathrm{t}^{-1}$ protease and $\mathrm{T}_{5}=$ negative control + $500 \mathrm{~g} \mathrm{t}^{-1}$ protease. 